\title{
The recurrent approach to the study of innovative economic development
}

\author{
Oksana Butorina $^{1 *}$, and Irina Shishkina ${ }^{2}$ \\ ${ }^{1}$ Perm National Research Polytechnic University, Perm, 614990, Russian Federation, \\ ${ }^{2}$ Perm State National Research Polytechnic University, Perm, 614990, Russian Federation,
}

\begin{abstract}
The recurrent approach is an integrated approach that combines existing studies of cyclic macroeconomic processes, taking into account the nature of their intercyclic and interphase dependencies. According to this approach, the innovative economy is a natural phase of depression (interphase transition from the neo-industrial economy to the information innovative economy) within the modern transformation cycle. Recognition of the significance of the depression phase allows us to assert that the innovative economy has a twofold nature; it intertwines the processes characteristic of the neo-industrial economy, and forms processes that ensure a "breakthrough" to the neo-economy. In other words, it is dependent on the neoindustrial processes, implying increased digitalization, and becomes the basis for the development of the neoeconomy. Taking into account the objectivity of the twofold nature of the innovative economy, it can be argued that it is a special type of the economic system based on a continuous stream of innovations, constant technological improvement, production and export of high-tech products with high added value and technologies, determined by a combination of information, technological, investment, industrial, structural and social transformations.
\end{abstract}

\section{Introduction}

In modern world science, the entire set of macroeconomic processes is considered to be the basis for a new type of cycle. Kleinknecht and Van der Velde point out that modern economic development, due to its uniqueness based on direct and inverse relationships between the basic macroeconomic processes, cannot be limited to studies of traditional short-term, medium-term and long-term cycles. Glazyev, Ajvazov and Belikov focusing on the priority of objective technological transformations, associate the macroeconomic processes with the transition from the industrial to postindustrial economy [6].

On the basis of numerous studies of the current development of the domestic and world economic systems, the basic processes of the transition stage can be identified. These include

- formation, dissemination, commercialization of new knowledge embodied in material means and objects of labor, which transforms social production and ensures the accumulation and dissemination of information, innovation and technological progress [1];

- structural changes in production and in the economy as a whole, implying an increase in the share of the non-industrial sector in the value of the goods, based on the development of digital and IT industries;

- large-scale development of innovations in the production and non-production spheres of human life [1];

- increasing the efficiency of innovations based on the effective global and national markets for innovations, based on the market mechanism dependent on the aggregate action of the market laws: demand, supply, equilibrium price, competition, value and money circulation;

- transformation of labor resources from the mechanical "producing" process it becomes "creative" based on qualitative changes in the human capital through the commercialization and industrialization of knowledge and individual's ability to increase intellectual property [8];

- improving science intensity and technotronic potential of production technologies, which implies an increase in the share of R\&D costs, constant renewal, transformation of means of production by implementing breakthrough technologies;

- search and implementation of new forms of investment support for the economic development, creation of the monetary and informational forms of capital. MIFC is investment resources in real assets through the digital and IT technologies. These may include crowdfunding, crowdlending, crowdinvesting and P2P lending. In a broad sense, the MIFC as an independent form of capital associated with the selfincreasing cost of investments in the development of information and labor resources to create new high-tech products capable of independently increasing surplus value.

\section{Materials and methods}

The uniqueness of the current state is based on the

\footnotetext{
* Corresponding author: ok.butorina@yandex.ru
} 
transformation of the industrial and post-industrial eras: the objectivity of reasons for the formation of a transformational crisis, the duration and amplitude of cyclical fluctuations, specification of processes, forming the uniqueness of the modern macroeconomic state, emphasizing direct and inverse relationships between these processes.

Expansion of the range of research areas of cyclic processes has actualized the search for new methodological approaches. Along with the traditional dialectical and systemic approaches, we consider it expedient to use a new methodological approach to the study of modern macroeconomic processes, taking into account the nature of their intercyclic and interphase dependencies.

\section{Results and discussion}

Due to the uniqueness of the modern macroeconomic cycle, the authors suggest using the recurrent approach, which can be considered as a synthesis of existing studies of cyclic processes. Its main provisions can be formulated as follows:

- in terms of the cyclical dynamics, recurrence is a general economic regularity, which is a multilevel, multifactorial, multi-criteria characteristic of specific dependencies of various cycles and their internal phases. It makes it possible to reveal causal relationships between the phases within each cycle and between the cycles that form the general macroeconomic pulsation;

- specification of the macroeconomic processes of the modern transition period from the industrial era to the post-industrial era can become the basis for identifying basic cycles that are in direct and inverse relationships with each other. The list of these cycles is determined by the researcher based on the purpose of the study, therefore it is not devoid of subjectivity and requires additional justification of the choice. These cycles are identified based on the processes that describe current transformational changes;

- the presence of a relationship between macroeconomic processes, which is formed by the essential characteristics of the cause-and-effect relationships between them and is defined as an intercyclical recurrence. When characterizing the relationships, it is necessary to take into account that each cycle is characterized by its own amplitude, time duration and a system of indicators. The cycles can be divided into several groups: 1) cycles of a providing nature (their phase state forms the basis of the states of the cycles interconnected with them, acting as factors of its dynamics), 2) the cycles that characterize the transformation of macroeconomic processes; 3) the cycles reflecting the effectiveness and / or completeness of the transformation at each stage;

- recognition of the existence of recurrent dependencies between the cycles can become the basis for the development of a comprehensive methodology for assessing the current state and subsequent mediumterm and long-term forecasting of the cyclical dynamics of economic systems;
- the intercyclical and interphase recurrent dependencies can specify directions and methods of management of the cyclical processes in the economy, increasing the effectiveness of countercyclical policies in the regions and the country as a whole.

The recurrent approach has become the methodological basis for the study of the modern macroeconomic cycle.

The current macroeconomic cycle can be interpreted in two ways. Within the narrow approach, the modern macroeconomic cycle is a special unique type of cycle that has a transformational nature, within which the information cycle, as an independent type of cycle, can be considered as a cycle of an opportunistic nature, while the technological, innovation, investment cycles are production cycles, and the social and structural cycles are resultant.

In a broad sense, the modern macroeconomic cycle is a system of intra-phase transitions within the industrial and post-industrial mega-cycle, which are characterized by the uniqueness of transformation of the forms of economic development. The system of intra-phase transitions includes the transition from the industrial to neo-industrial economy (the phase of the crisis within the modern macroeconomic cycle), from the neoindustrial to information and innovation (depression phase) economy, from the innovation and information to neo-economy (exhilaration phase), from the neoeconomy to the "knowledge economy" or post-industrial economy (recovery phase).

This interpretation can be interesting for identifying the nature of the innovative economy, as a natural phase of depression (interphase transition from the neoindustrial to the information-innovative economy) within the modern transformation cycle. Karl Marx considered the depression phase as the main phase of any cycle. It is in it that the last crisis processes fade away and new ones arise, ensuring the progressive development (transition to the phases of revitalization and recovery), and determining the general vector of the incipient new cycle. Recognition of the significance of the depression phase allowed us to assert that the innovative economy has a twofold nature; it intertwines the processes characteristic of the neo-industrial economy, and forms processes that ensure a "breakthrough" to the neoeconomy. In other words, it is dependent on the completeness of neo-industrial processes, implying increased digitalization, but it also becomes the basis for the neo-economy.

Taking into account the objectivity of the twofold nature of the innovative economy, it can be argued that it is a special type of the economic system based on a continuous flow of innovations, constant technological improvement, production and export of high-tech products with high added value determined by a combination of information, technological, investment, industrial, structural and social transformations. Tables 1 and 2 present the characteristics of the innovative economy within the interphase transition from the neoindustrial economy and from the innovative economy to the neo-economy in terms of the intercyclical recurrence. 
Table 1. Features of the innovative economy within the interphase transition from the neo-industrial economy in terms of the intercyclical recurrence

\begin{tabular}{|c|c|c|}
\hline $\begin{array}{l}\text { Transformational } \\
\text { processes within the } \\
\text { inter-cycle } \\
\text { recurrence }\end{array}$ & $\begin{array}{l}\text { Characteristics of } \\
\text { transformation processes }\end{array}$ & $\begin{array}{l}\text { Degree of } \\
\text { transformational } \\
\text { transition }\end{array}$ \\
\hline $\begin{array}{l}\text { Informatization } \\
\text { processes }\end{array}$ & $\begin{array}{l}\text { - commercialization of } \\
\text { information; } \\
\text { - socialization of } \\
\text { information; } \\
\text { - use of ICT in } \\
\text { production, } \\
\text { management, } \\
\text { communication, } \\
\text { entertainment [5] } ;\end{array}$ & $\begin{array}{l}\text { - use of ICT in } \\
\text { all spheres of the } \\
\text { economy and } \\
\text { human life }\end{array}$ \\
\hline $\begin{array}{l}\text { Technological } \\
\text { transformation } \\
\text { processes }\end{array}$ & $\begin{array}{l}\text { - computerization as the } \\
\text { basis for digitalization; } \\
\text { - massive digitalization; } \\
\text { - increasing the level of } \\
\text { automation, robotization; } \\
\text { - high technology } \\
\text { technotronic } \\
\text { industrialization; }\end{array}$ & $\begin{array}{l}\text { - dominance } \\
\text { of V - VI } \\
\text { technological } \\
\text { orders; }\end{array}$ \\
\hline Innovation processes & $\begin{array}{l}\text { - development } \\
\text { of innovation; } \\
\text { - development of } \\
\text { borrowed innovations; } \\
\text { - development of own } \\
\text { innovations }\end{array}$ & $\begin{array}{l}\text { - the continuity } \\
\text { of the process of } \\
\text { generating their } \\
\text { own, not } \\
\text { borrowed } \\
\text { innovations [2]. }\end{array}$ \\
\hline $\begin{array}{l}\text { Investment } \\
\text { provision processes }\end{array}$ & $\begin{array}{l}\text { - flourishing of venture } \\
\text { capital; } \\
\text { - electronic payment } \\
\text { systems }\end{array}$ & $\begin{array}{l}\text { - stable } \\
\text { investment } \\
\text { support for the } \\
\text { innovation sector }\end{array}$ \\
\hline $\begin{array}{l}\text { Manufacturing } \\
\text { processes }\end{array}$ & $\begin{array}{l}\text { - creation of new } \\
\text { products; } \\
\text { - creation of new } \\
\text { business models based } \\
\text { on the capabilities of the } \\
\text { digital economy [4]; }\end{array}$ & $\begin{array}{l}\text { - accelerating the } \\
\text { pace of } \\
\text { economic } \\
\text { development; } \\
\text { - high production } \\
\text { efficiency based } \\
\text { on cost reduction }\end{array}$ \\
\hline $\begin{array}{l}\text { Structural } \\
\text { transformation } \\
\text { processes }\end{array}$ & $\begin{array}{l}\text { - development of e- } \\
\text { commerce; } \\
\text { - development of new } \\
\text { industries within } \\
\text { the ICT; } \\
\text { - priority importance of } \\
\text { "critical industries" } \\
\text { capable of increasing the } \\
\text { surplus value; } \\
\text { - development of the } \\
\text { knowledge industry [8]. }\end{array}$ & $\begin{array}{l}\text { - the formation } \\
\text { of a new } \\
\text { economy } \\
\text { focused on } \\
\text { knowledge } \\
\text { derived from } \\
\text { information [4]. }\end{array}$ \\
\hline $\begin{array}{l}\text { Social } \\
\text { transformation } \\
\text { processes }\end{array}$ & $\begin{array}{l}\text { - formation of new } \\
\text { sources of income by } \\
\text { increasing the share of } \\
\text { intellectual property; } \\
\text { - intellectualization of } \\
\text { workers' labor; } \\
\text { - large-scale } \\
\text { capitalization of } \\
\text { professional and } \\
\text { intellectual abilities }\end{array}$ & $\begin{array}{l}\text { - the created } \\
\text { knowledge } \\
\text { industry as a } \\
\text { mechanism for } \\
\text { building up } \\
\text { human capital } \\
\text { [7]; } \\
\text { - an increase in } \\
\text { the quality of life }\end{array}$ \\
\hline
\end{tabular}

The following conclusions can be drawn:

- at the present stage of the innovative economy formation and development, the priority is given to the processes of informatization. It based on the large-scale use of information and communication technologies in all spheres of the economy and people's life. At the same time, the conjunctural nature of informatization as a process should be particularly noted. In other words, it is basic for technological, industrial, structural, and social transformations.
Table 2. Features of the innovative economy within the interphase transition from the innovative economy to the neoeconomy in terms of the intercyclical recurrence

\begin{tabular}{|c|c|c|}
\hline $\begin{array}{l}\text { Transformational } \\
\text { processes within the } \\
\text { framework of inter- } \\
\text { cycle recurrence }\end{array}$ & $\begin{array}{l}\text { Characteristics of } \\
\text { the } \\
\text { transformation } \\
\text { process }\end{array}$ & $\begin{array}{l}\text { Degree of } \\
\text { transformational } \\
\text { transition to } \\
\text { the innovation } \\
\text { and information } \\
\text { economy }\end{array}$ \\
\hline $\begin{array}{l}\text { Informatization } \\
\text { processes }\end{array}$ & $\begin{array}{l}- \text { constancy of } \\
\text { informatization } \\
\text { and generation of } \\
\text { knowledge and } \\
\text { innovations }\end{array}$ & \begin{tabular}{|l} 
- formation of a \\
stable \\
dependence of \\
productivity on \\
information and \\
management \\
quality
\end{tabular} \\
\hline $\begin{array}{l}\text { Technological } \\
\text { transformation } \\
\text { processes }\end{array}$ & $\begin{array}{l}\text { - dominance in } \\
\text { all sectors of the } \\
\text { ICT economy, } \\
\text { transforming the } \\
\text { material basis of } \\
\text { the modern world }\end{array}$ & $\begin{array}{l}- \text { technology for } \\
\text { the dissemination } \\
\text { of knowledge }\end{array}$ \\
\hline Innovation processes & \begin{tabular}{|l} 
- innovation \\
of production \\
based on the \\
mass \\
transmission of \\
knowledge and \\
innovations
\end{tabular} & $\begin{array}{l}\text { - development of } \\
\text { the innovative } \\
\text { potential of the } \\
\text { national } \\
\text { economy }\end{array}$ \\
\hline $\begin{array}{ll}\text { Investment } & \text { provision } \\
\text { processes } & \\
& \\
\end{array}$ & $\begin{array}{l}\text { - creation of new } \\
\text { forms of capital } \\
\text { (monetary and } \\
\text { informational } \\
\text { form of capital) }\end{array}$ & \begin{tabular}{|l|} 
accelerated \\
development \\
based $\quad$ on \\
intangible assets \\
and intangible \\
components of \\
the economy \\
\end{tabular} \\
\hline \begin{tabular}{|l|} 
Manufacturing processe \\
s
\end{tabular} & \begin{tabular}{|l|} 
- production of \\
intelligent \\
products
\end{tabular} & $\begin{array}{l} \\
\text { intellectualizatio } \\
\text { n of production }\end{array}$ \\
\hline $\begin{array}{l}\text { Structural } \\
\text { transformation } \\
\text { processes }\end{array}$ & $\begin{array}{l}\text { predominance } \\
\text { of industries that } \\
\text { create intellectual } \\
\text { products }\end{array}$ & \begin{tabular}{|lr}
- & self- \\
development & of \\
intelligent & \\
technologies & and \\
industries that & theate intelligent \\
creaducts [7].
\end{tabular} \\
\hline $\begin{array}{l}\text { Social transformation } \\
\text { processes }\end{array}$ & $\begin{array}{l}\text { intellectualizatio } \\
\text { n of labor }\end{array}$ & $\begin{array}{l}\text { - constancy of } \\
\text { the increase in } \\
\text { the value of the } \\
\text { human factor of } \\
\text { production as the } \\
\text { only transformer } \\
\text { of knowledge }\end{array}$ \\
\hline
\end{tabular}

Informatization defines the general vector of the cycles identified by us, connected with each other by recurrent dependencies within the modern macroeconomic cycle. Today the essence of the technological cycle is characterized by the knowledgeintensive technotronic industrialization of the economy, the essence of innovatioal cycle characterized by the continuous process of generating its own (national) innovations rather than borrowed, the essence of the investment cycle characterized by the innovation sector stable investment provision, the essence of the production cycle characterized by the essence of the 
structural cycle is the formation of knowledge industry new branches and their development within the boundaries of ICT, focused on the continuous increase of surplus value in the long term, the essence of the social cycle characterized by the formation of new sources of income based on increasing the share of intellectual property, as well as the increase of "traditional" income based on large - scale capitalization of professional and intellectual abilities. Based on this, we consider it possible to define this phase of the modern macroeconomic cycle as an innovation and information one;

- the above-mentioned essential processes can be considered as conditions for the transition to a new more macroeconomic cycle progressive phase. Move from the innovation and information economy to the neoeconomy and / or the knowledge economy. At the same time, within the framework of this transformational transition, the process of intellectualization can be distinguished as a conjunctural one. It can determine the general direction of the dynamics of cyclic processes. Thus, the essence of the information cycle can be determined by the stability of the dependence of productivity on the use of information and the quality of management, the essence of technological cycle can be determined by the formation of technologies for the dissemination of knowledge, the essence of innovative cycle can be determined by the continuous increase in innovative potential, the essence of the investment cycle can be determined by the stable increase in the use of intangible assets and the intangible component of management as a whole, the essence of the production cycle can be determined by strengthening the intellectualization of production, the essence of the structural cycle can be determined by ensuring the continuous self-development of intelligent technologies and industries that create intelligent products, the essence of the social cycle can be determined by the constant increase in the value of the human factor of production as the only converter of knowledge.

Based on the presented features of the cyclical processes that determine the phase transformation transitions within the modern macroeconomic cycle, the concepts of both "innovation economy" and "knowledge economy" can be concretized.

The term "knowledge economy" was introduced in 1962 by F. Machlup characterizing the economic system of the post-industrial era. Modern economists interpret it in a similar way. L.M. Gokhberg believes that this is an economy that is based on the effective application of knowledge. G.B. Kleiner defines knowledge as a product with unique properties that are a factor of production [7]. Based on these interpretations, the processes of the information-innovative phase can be identified:

1) formation of a stable dependence of productivity and production efficiency on the use of the achievements of science and technology and the quality of information and management;

2) dominance of information activities as a zone of mutual interests of producers and consumers;
3) continuous transformation of the production process (from standardized to "customized");

4) globalization of the economy, as a result of which capital, production, management, markets, labor, information and technology can function beyond the national boundaries;

5) constancy of technological changes based on the accelerated development and use of intangible assets and the intangible environment of economic activity.

These processes are basic, they can be differentiated and / or unified based on the purpose of the study.

\section{Conclusion}

Thus, the recurrent approach is an integrated approach, which is a synthesis of available studies of cyclic processes, taking into account the nature of intercyclic and interphase dependencies. The innovative economy is a natural phase of depression (interphase transition from the neo-industrial economy to the informationinnovative economy) within the modern transformation cycle. Recognition of the significance of the depression phase allowed us to assert that the innovative economy has a twofold nature; it intertwines the processes characteristic of the neo-industrial economy, and forms processes that ensure a "breakthrough" to the neoeconomy. In other words, it is formed under the influence of completed neo-industrial processes, implying increased digitalization, but it also becomes the basis for the development of the neo-economy. Taking into account the objectivity of the twofold nature of the innovative economy, it can be argued that it is a special type of the economic system based on a continuous flow of innovations, constant technological improvement, production and export of high-tech products with high added value. At the same time, transition to the information-innovative economy is ensured by digitalization and innovation processes, and to the neoeconomy - by intellectualization of production and economic processes in general.

\section{References}

1. I.A. Sushkova Information security of regions 4 (25) (2016)

2. J.S. Metcalfe, J. Foster, R. Ramlogan Cambridge Journal of Economic, 30(1), 7-32 (2006).

3. T. Romanova Digital economy in Russia. Retrieved from: http://fb.ru/article/334484/tsifrovaya- ekonomika $-\mathrm{v}-$ rossii

4. K.V. Ilyina Izvestiya SPbGEU, 3 (117), (2019)

5. R.M. Nureev, O.V. Karapayev Journal of economic regulation, 10 (2), (2019)

6. O.V. Butorina, E.A. Tretyakova Bulletin of the Perm University. Ser. "Economy", 14 (2), 289312, (2019) 
7. G.N. Stepanova, E.V. Krasilnikova Bulletin of Moscow State University named after Ivan Fedorov, 3, 88-93, (2016)

8. A. A. Volkova, V. A. Plotnikov, M. V. Rukinov, Management consulting 4 